\title{
Model Productivity in UKM Coconut Oil based on Information Technology in North Sulawesi
}

\author{
Marike A. S. Kondoj \\ Information Technology Dept \\ Manado State Polytechnic \\ North Sulawesi - Indonesia
}

\author{
Herry S. Langi \\ Information Technology Dept \\ Manado State Polytechnic \\ North Sulawesi - Indonesia
}

\author{
Sonny R. Kasenda \\ Electrical Engineering Dept \\ Manado State Polytechnic \\ North Sulawesi - Indonesia
}

\begin{abstract}
The need for tools in the field of information technology in decision-making at the time of control coconut oil production will be necessary given the absence of specific applications for it. To develop the Software planned this study will begin by conducting a survey on UKM coconut oil in northern Sulawesi to get the data analysis so that a complete picture fried coconut oil processing system and can describe the problem and the solution are clear. By using RUP for the development of the system, the data obtained were analyzed using several methods of design are flowcharts, data flow diagrams and entity relationship diagram so that it can generate a software which can be used in UKM Information Technology based in North Sulawesi that can be used to help process the fried coconut oil UKM.
\end{abstract}

\section{General Terms}

Models Aplication system, web technology, UKM

\section{Keywords}

Software, UKM, Technology

\section{INTRODUCTION}

Indonesia is a country that has a lot of natural resources and other potentials that could make Indonesia become economically advanced countries so as to enable the economy to create fair and equitable. One agricultural commodity that has a strategic position in Indonesia is palm plants (Cocos nucifera. L). Production of plantation sector sub-highest occupied by oil palm commodity with a total production amounted to $23,521,071$ tons, is very high when compared to another commodity. The second position is occupied by oil commodity with a total production of $3,176,223$ tons. (Journal Emba).

According to Kaunang Willy, one of processed coconut products are considered able to contribute to the economy of North Sulawesi, namely oil. Coconut oil is one of the commodities that are excellent in North Sulawesi. The leading commodity exports topped North Sulawesi from year to year [1].

So far, farmers rely on coconut copra oil production only made it and sold to collectors. So the farmers' income is only focused on income from the sale of copra alone when farmers can produce their own white coconut oil with the results of the coconut itself or from buying oil from fellow farmers. When farmers produce palm oil it means that farmers can benefit more than just making copra alone and could open up the jobs for the community.

Because there are many opportunities for UKM in North Sulawesi coconut oil to make the famous fried coconut oil is healthier than palm oil. To support the manufacture of cooking palm oil production will require good control of the manager or the management so that it can meet the demand for palm oil.

According to sipper \& Bulfin Jr., Production Planning, Control, and Integrations, productivity in the production can be done by having a production schedule to anticipate demand, what more demand for products that are more and more so that the allocation of raw materials and labor requires good planning.

Likewise with producing coconut oil cooking in addition to knowledge of how or procedures produce palm oil fries were good, business people or entrepreneurs small and medium businesses also requires knowledge, how it can meet the demand for palm oil cooking of consumers, let alone demand trends in the greater or much in the period a period of next 6 months to 1 year. Producing good is based on the planning and controls so that the use of raw materials and labor costs can be efficient and effective (Bedworth D.D., Bailey J.E., Integrated Production Control System) [2].

Opportunities to profit from own making very big that coconut oil has proved to be useful also for health, proven today began much sought after to solve health problems by Cahyorini Kusumawardani.

\section{METHODOLOGY}

A. Methods

The method used in the development system is a method of RUP (Rational Unifed Process). System development methods RUP is done iteratively (repeating) and incremental (gradual with progress upward) [4]

RUP has four phases conducted sequential and iterative where each iteration can used to improve the next iteration.

1. Inception (starters) is a stage model the business processes required and defines the need for the system to be created.

2. Elaboration (extension / planning), is more focused on planning the system architecture. This stage can also be made to determine whether the desired system architecture can be made or not. This stage also gives emphasis on the analysis of the system design and system implementation and expected results of this phase is to fulfill the Lifecycle Architecture Milestone (boundary / architectural milestones of the cycle)

3. Construction (Construction), this stage is more focused on the development of a component or system features. 
4. Transition (Transition), this stage is the deployment or installation of the system in order to be understood by the user. Activities at this stage included in user training, maintenance, and testing of the system is to meet user expectations.

\section{B. System Design Research}

Based on research that has been done before with the view that the viability of the business, the coconut oil in this study, researchers will be developing a web-based software because it was felt the need for this application will assist UKM in doing business. The integrated application model that will be developed involve three parts, namely sales, production and supply of raw materials. The system will connect request to order production so that when there is demand for cooking oil then the request will be entered into the system at sub-order and will be in if the server to be used by the production department to determine production and production schedules. Having obtained the required amount to be produced and the resources required, the data will be stored on a server that can later be used to control raw materials and ordering.

\section{RESULT AND DISCUSSION}

A. Device Analysis

1. Flowchart. Based on the survey conducted, it was found that the business process will be undertaken in some UKM are not yet integrated with the computer. End - the end of the business which is run by UKM coconut oil experienced a very slow growth. Therefore it is necessary to do an in-depth analysis to develop tools that can help UKM in controlling the process of productivity in UKM. There is some productivity in the analysis, starting from the input, process, and output., The process will be carried out sequentially. Some sections will set the course of the production process from raw material availability, booking process until the transactions that occur are recorded in the form of reports reports for each part. This flowchart should describe the system as a whole. The flowchart below shows the order and relationship between the process with instructions.

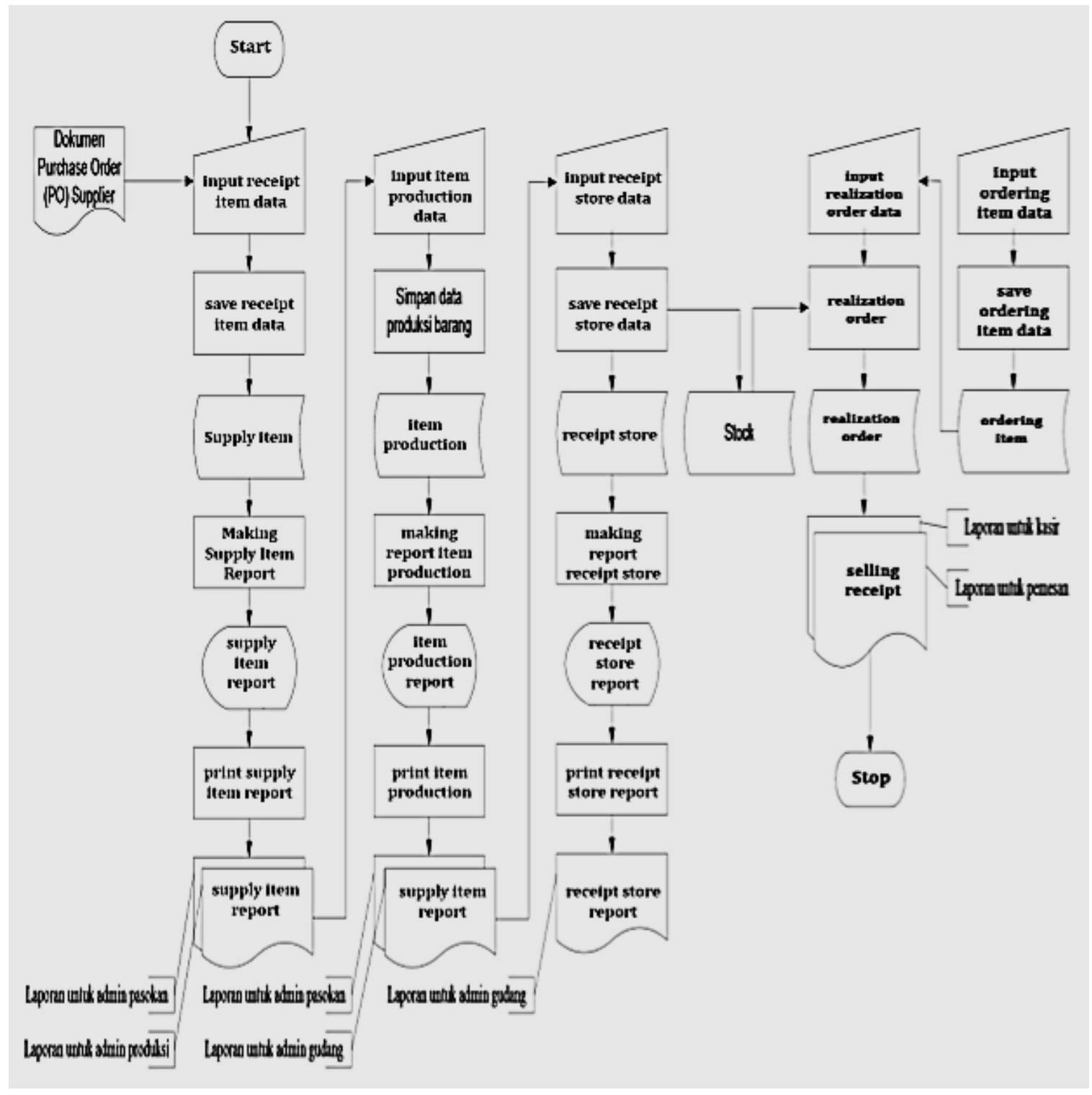

Fig 1: System Flowchart

2. Data Flow Diagrams (DFD). DFD is made for the purposes of analysis and design structured to make it easier to 
understand the system and sub-system virtually as a series of interrelated data stream. The figure below is a diagram used for the analysis system.

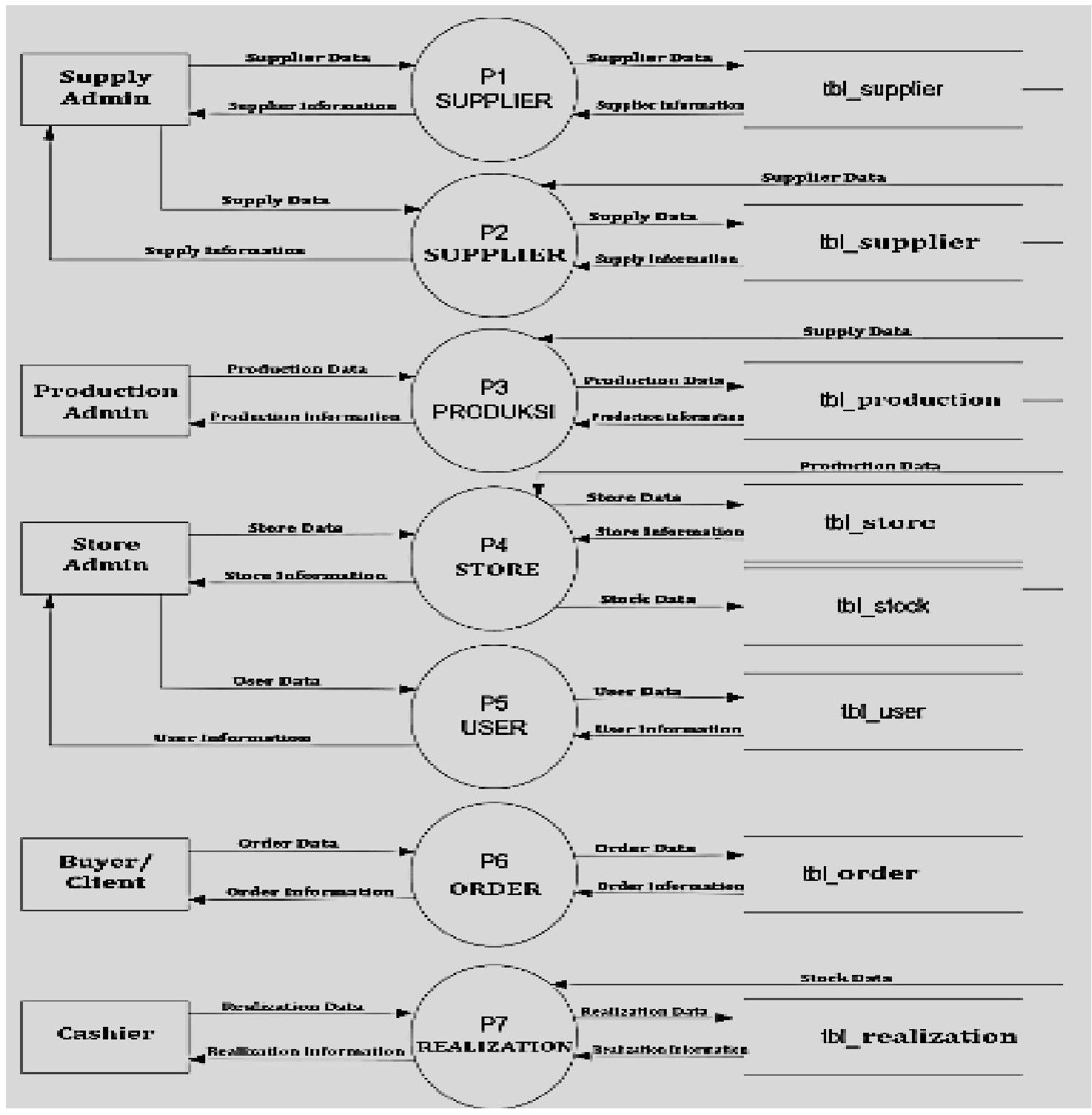

Fig 2: The initial design of the interface

The figure above shows that the system interacts with outside entities 5 interconnected that supply admin, admin production, admin store ,supply and cashier by running 7 process.

3. Design Interface. An interface should be designed with a good visual display and ergonomics (Wignjosoebroto, 2000) [5]. The interface was developed based on the analysis that has been done on several previous descriptions. The figure below presents the user interface design of applications that are built:

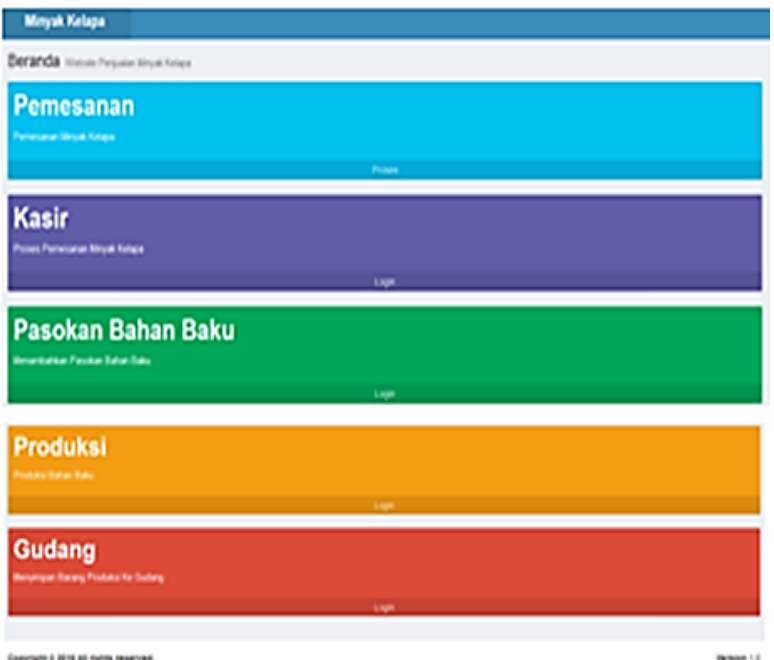

Fig 3: The initial design of the interface 
From the picture above get navigation information available, namely: Order, Cashier, Raw Material Supply, Production and Warehouse that each - each part has a login to System different - different.

5. Testing System. The design of this study is based on usability aspects. Usability helps companies understand Reviews their customers and a usable product is Recognized, used, and recommended (Kleinresearch, 2006) [5]. To measure / test the usability of the application made to get variables - variables usability data collection is done by distributing questionnaires to the respondents. The questionnaire is a short way to collect some random data into how users assess the existing system [6]. Of the 60 respondents, 10 of them have access to an application / system information via the Internet and have sufficient knowledge in developing applications, while 50 respondents are that they do not have knowledge in information systems such as UKM which this application will be used.
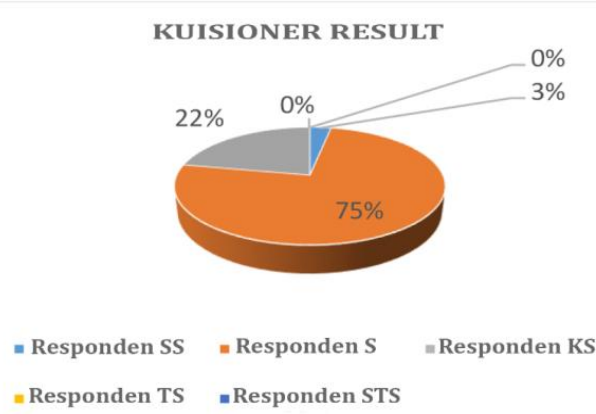

Figure 4. Test Results Respondents.

From the above chart the information is presented that 45 respondents agreed that the existing application has a variable - variable usability, 13 respondents expressed less agreed and
2 respondents strongly agree with the reasons that have been put forward.

\section{CONCLUSION}

The developed application useful for controlling the balance between the availability of raw materials to production so that no have excess or shortage of raw materials.

Based on the test usability of respondents it can be concluded that the model is generated can help UKM in running the business and implemented in UKM as a tool for an application that is easy to learn and use, in accordance with the needs and can provide the information needed to make it easier in terms of documentation business. $75 \%$ of respondents agreed to the implementation of applications in UKM.

\section{REFERENCES}

[1]. Kaunang Willy, 2013, Daya Saing Ekspor Komoditi Minyak Kelapa Sulawesi Utara, Jurnal Emba 1315 Vol.1 No.4 Desember 2013

[2[. Bedworth D.D., Bailey J.E., 1987,Integrated Production Control System, John Wiley \& Sons,

[3]. Jogiyanto., 2005, Analisis dan Disain Sistem, Penerbit Andi

[4]. Chen Q, "Compare and study about owing to the three kinds important softwaresdevelop process", Proceeding of the International Conference on Education Technology and Economic Management (ICETEM) 450-451. 2015

[5].http://digilib.its.ac.id/public/ITS-Undergraduate-88772504100030-Paper.pdf7. Tanggal akses 24 Okt 2016

[6]. Kendall \& Kendall, Analisis dan Perancangan Sistem, Edisi Kelima, Prehallindo, Jakarta. 